DOI https://doi.org/10.18551/rjoas.2020-12.15

\title{
IMPACT OF ORGANIC FERTILIZER ON PRODUCTIVITY OF RICE FARMING IN NGAWI REGENCY OF EAST JAVA, INDONESIA
}

\author{
Saeri M.* \\ Assessment Institute for Agricultural Technology, East Java, Indonesia \\ Rahman M.S. \\ Faculty of Agriculture, University of Brawijaya, Indonesia \\ *E-mail: saerimoh@yahoo.com
}

\begin{abstract}
This study aimed to analyze the decisions of farmers in the use of organic fertilizer and analyze the impact of the use of organic fertilizers on productivity and farm income. This study was conducted in Ngawi regency of East Java Province. A total of 88 farmers of paddy were used as respondents in this study. The logit regression and propensity score matching (PSM) were used to examine factors affecting farmers to adopt organic fertilizers and the impact of organic fertilizer on the productivity of rice farming. The results of the study showed field school, farmer ages, farmers 'education level and participation in farmer groups had a positive and significant influence on farmers' decisions to use organic fertilizer. Furthermore, the results of the PSM analysis show that farmers who use organic fertilizer obtain higher production than farmers who do not apply. This can be stated that the use of organic fertilizers is able to provide higher productivity and better agricultural sustainability.
\end{abstract}

\section{KEY WORDS}

Organic fertilizer, Logit regression, PSM, production.

In the last decades, the intensification of agriculture is one of the solutions to meet food needs in developing countries. Agricultural intensification is characterized by land management that aims to maximize agricultural productivity often use chemicals such as chemical fertilizers and pesticides. The high use of chemicals in agriculture has been shown to have a negative impact on the sustainability of the environment; the natural balance will be disturbed by the emergence of resistant pests and parasites (Carvalho, 2006). A study carried out by (Deknock et al., 2019) in the State of Ecuador shows that the use of chemicals is one factor that has tainted many waters clean. On the other hand, the use of chemicals in the agriculture sector also had a negative impact on the socio-economic conditions, welfare, and food security (Alavanja, 2009; Carvalho, 2006). Furthermore, various researchers have proved that the excessive use of chemicals causes various diseases for the perpetrators of farming, (Boone, et al. 2019; Jayakumar, et al. 2020). The World Health Organization (WHO) and the United Nations Environment Program (UNEP) estimates that every year, there are 3 million farmers in developing countries suffered poisoning caused by chemicals in agricultural activities (Miller \& Meek, 2004). Unfortunately, various literature demonstrates the use of chemical fertilizers in various countries is increasing from year to year (Alavanja, 2009; Jayakumar et al., 2020; Mfarrej \& Rara, 2019) One of them in the State Indonesia.

The impact of the use of chemicals has been felt by the community in Indonesia, FAO (2018) explained that as many as $69 \%$ of land in Indonesia suffered damage and caused a decline in soil productivity caused by the high use of chemicals. The results of the study conducted by (Jenni, et.al, 2014) shows that the majority of the flow of water used for agriculture in Indonesia contains chemicals. One of the efforts that have been recommended by many researchers to minimize the use of chemicals in agriculture is organic fertilizer. In addition to environmental sustainability is the reason, the use of organic fertilizers is also able to maintain the health and safety of farmers due to the use of chemicals (Cacek \& Langner, 1986). 
Various studies have proven that the use of organic fertilizer had a significant impact on the continuity of agriculture, welfare, and food security of farmers (Boone et al., 2019; Eyhorn et al., 2019; Shahrajabian, et.al. 2019). Although the use of organic fertilizers has been shown to increase the sustainability of agriculture, many farmers are reluctant to do so. This is because of each farmer's perceptions and different socio-economic conditions. To overcome these problems the study sought to examine the factors that determine the decision of farmers to adopt organic farming and to analyze how the impact of organic farming on the production of farming activities.

\section{METHODS OF RESEARCH}

The data used in this research is primary data obtained from the results of a survey of rice farmers in Ngawi regency of East Java province, which is focused in the District Widodaren. The choice of location was purposive with consideration of the area is a granary in East Java and not all rice farmers in these locations using organic fertilizers. The variables collected include socio-economic conditions of farmers, rice farmers' decision to use organic fertilizer, rice production, and economic value. Determination of the number of respondents using slovin and gained as much as 88 respondents.

The method used to determine the factors that influence the decisions of farmers to adopt organic farming is logit regression analysis. Logit regression can be used when the dependent variable $(Y)$ is binary. In this study, the dependent variable used is the farmer's decision to use organic fertilizers (do $=1$ does and does not do $=0$ ) while the independent variables consist of field school $(x 1)$ the number of families $(x 2)$ age $(x 3)$ education $(x 4)$ experience ( $x 5$ ) participation in farmer groups $(x 6)$ land ownership status ( $x 7)$.

The mathematically logistic regression model in this study can write as follows:

$$
\operatorname{Ln}\left[\frac{\pi}{1-\pi}\right]=\beta_{0}+\beta_{1} X_{1}+\beta_{2} X_{2}+\beta_{3} X_{3}+\beta_{4} X_{4}+\beta_{5} X_{5}+\beta_{6} X_{6}+\beta_{7} X_{7}+\beta_{8} X_{8}+e
$$

Likelihood ratio tests are used to review the influence of independent variables on the dependent variables together or simultaneously. In this testing logit regression is done using the Likelihood Ratio. The hypothesis in this test is:

$$
\mathrm{HO}: \beta 1=\beta 2=\beta 3=\beta 4=\beta 5=\beta 6=\beta 7=\beta 8=\beta 9=\beta 10=0
$$

Statistically independent variable income field school $(x 1)$ the number of families $(x 2)$ age (x3) education (x4) experience (x5) participation in farmer groups (x6) Land ownership status $(x 7)$ no effect simultaneously on the dependent variable, namely the use of fertilizers organic $(\mathrm{Y})$.

Ha: at least one $\beta i \neq 0, i=(1,2,3,4,5,6,7)$ or if $X 2>X 2(n-k)$ or a $p$-value $<a$

Statistically independent variable income field school $(x 1)$ the number of families $(x 2)$ age (x3) education (x4) experience (x5) participation in farmer groups (x6) Land ownership status (X7) effect simultaneously on the dependent variable is the use of organic fertilizers (Yi). Partial Test in logit regression using the Wald test. The purpose of the wald test is to determine the effect of independent variables on the dependent variable partially. The hypothesis to conduct a partial test in this study are:

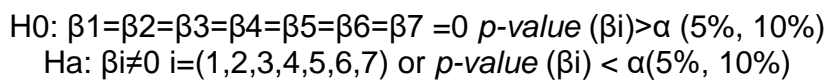

Hypothesis 1:

- If the $p$-value $(\beta 1)>\alpha(5 \%, 10 \%)$, then $\mathrm{Ho}$ is accepted and Ha rejected meaning that the field school does not significantly influence the farmer's decision to use organic fertilizers; 
- If the $p$-value $(\beta 1)<\alpha(5 \%, 10 \%)$, then Ho is rejected and Ha accepted means school field significantly influence the decisions of farmers to use organic fertilizers.

Hypothesis 2:

- If the $p$-value $(\beta 1)>\alpha(5 \%, 10 \%)$, then Ho is accepted and Ha rejected meaning that the number of families does not significantly influence a farmer's decision to use organic fertilizers;

- If the $p$-value $(\beta 1)<\alpha(5 \%, 10 \%)$, then Ho is rejected and Ha accepted means that the number of families significantly influence the decisions of farmers to use organic fertilizers.

Hypothesis 3:

- If the $p$-value $(\beta 2)>\alpha(5 \%, 10 \%)$, then $\mathrm{Ho}$ is accepted and Ha rejected meaning that age does not significantly influence the decisions of farmers to use organic fertilizers;

- If the $p$-value $(\beta 2)<\alpha(5 \%, 10 \%)$, then Ho is rejected and Ha accepted means to age significantly influence the decisions of farmers to use organic fertilizers.

Hypothesis 4:

- If the $p$-value $(\beta 3)>\alpha(5 \%, 10 \%)$, then $\mathrm{Ho}$ is accepted and Ha rejected meaning that education does not significantly influence the decisions of farmers to use organic fertilizers;

- If the $p$-value $(\beta 3)<\alpha(5 \%, 10 \%)$, then Ho is rejected and Ha accepted means of education significantly influence the decisions of farmers to use organic fertilizers.

Hypothesis 5:

- If the p-value $(\beta 4)>\alpha(5 \%, 10 \%)$, then $\mathrm{Ho}$ is accepted and $\mathrm{Ha}$ is rejected it means experience no significant effect on the farmer's decision to use organic fertilizers;

- If the $\mathrm{p}$-value $(\beta 4)<\alpha(5 \%, 10 \%)$, then $\mathrm{Ho}$ is rejected and $\mathrm{Ha}$ accepted means to experience a significant effect on the farmer's decision to use organic fertilizers.

Hypothesis 6:

- If the $p$-value $(\beta 5)>\alpha(5 \%, 10 \%)$, then Ho is accepted and Ha rejected meaning that participation in the farmers' group did not significantly influence the decisions of farmers to use organic fertilizers;

- If the $p$-value $(\beta 5)<\alpha(5 \%, 10 \%)$, then Ho is rejected and Ha accepted means of participation in farmers' groups significantly influence the decisions of farmers to use organic fertilizers.

Hypothesis 7:

- If the $p$-value $(\beta 6)>\alpha(5 \%, 10 \%)$, then $\mathrm{Ho}$ is accepted and $\mathrm{Ha}$ rejected meaning that the land status has no significant effect on farmer's decision to use organic fertilizers;

- If the $p$-value $(\beta 6)<\alpha(5 \%, 10 \%)$, then Ho is rejected and Ha accepted means of land status significant effect on the farmer's decision to use organic fertilizers.

Propensity Score Matching (PSM) is used to estimate the impact of organic fertilizer on rice farming productivity. The reason for using this method because adaptation is a process of self-selection for observed and unobserved variables. One of the reasons households do adopt can relate to income and food security. If we only compare the productivity between adopter and non-adopter, could cause the results of the comparison does not make sense because there will be selection bias. PSM method aims to overcome the problem of selection bias by forming a comparable household of each household characteristic. After the similar groups are formed, then will be a comparison between adaptation and non-adaptation.

PSM method begins by dividing the farmers into two groups, including adopter and non-group. If $\pi_{0 i}^{m}$ is the outcome for farmers who adopted $i$. the outcome for the farmer who adopted denoted $\pi_{1 i}^{m}$ and the outcome for not adopted denoted $\pi_{0 i}^{m}$. Then the difference in outcome between fishers who made the adoption and did not as following:

$$
\Delta_{i}=\pi_{1 i}^{m}-\pi_{0 i}^{m}
$$

If the impact can heterogeneous adopter between the household and only average impact was not identified, so: 


$$
A E=E\left(\pi_{1}^{m}-\pi_{0}^{m}\right)
$$

Problems in the estimation of equation 4 is the outcome of a farmers adopter in case non-adopter cannot be observed. The solution is to replace it with non-adopter groups. So the equation 4 will be the following equation:

$$
A E=E\left(\pi_{1}^{m}-\pi_{0}^{n m}\right)
$$

Where $\pi_{0}^{n m}$ is outcome for adopter group. Furthermore, If adaptation group randomly was drawn from a population, then:

$$
E\left(\pi_{1}^{m}\right)=E\left(\pi_{0}^{n m}\right)
$$

However, if adoption of organic fertilizer the decision-making process depends on the characteristics of households, so:

$$
E\left(\pi_{1}^{m}\right) \neq E\left(\pi_{0}^{n m}\right)
$$

The bias is called selection bias and can be addressed with the PSM method. Which requires a conditional independent assumption. In this case, the conditional independence assumption is the characteristic adoption, and non-adoption group is random. So that the adaptation decision is not related to the outcome.

Propensity Score defined by Rosenbaum and Rubin (1983) as the conditional probability adoption by taking into account the characteristics of respondents:

$$
p(X)=\operatorname{Pr}(m=1 \mid X)
$$

Where $m=1$ if farmers adopt and 0 if farmers do not adopt, and $X$ is a household characteristic variables. Furthermore, the propensity score requires balancing properties and can be written as follows:

$$
m \perp X \mid p(X)
$$
written:

Furthermore, combined with the assumption of conditional independence, and can be

$$
\pi_{0}^{m}, \pi_{1}^{m} \perp m \mid p(X
$$

This equation implies that if the adoption and non-adoption groups have the same propensity score, the average difference in the outcome of the two groups was the Unbiased Estimator of the AE (Rosenbaum \& Rubin, 1985).

\section{RESULTS AND DISCUSSION}

From Table 1 it can be seen that the respondents in this study average have attended the field school 1 time, while respondents' household members averaged 3-4 people. The age of farmers who are respondents is an average of 51.8 years. Furthermore, the level of education taken by farmers is an average of 7.7 years. The experience of respondents in farming activity is around 24 years. Most farmers who are respondents in this study have participated in farmer groups. While the land used in farming is mostly his own. Finally, namely rice production produced by each farmer an average of $7071 \mathrm{~kg}$. In addition to knowing the variables used in this study, we can also find out how the economic social conditions of farmers who are respondents in this study.

Logit regression analysis was used to answer questions about the factors that affected farmers' decision to use organic fertilizers. logit regression analysis results are shown in 
Table 2. The results of logit regression analysis obtained significant results Pseudo R2 of 0.0000 and 0.7826 , meaning that the model used in this study had good (fit). Furthermore, the influence of each independent variable is known that the field school, farmers' age, level of educator, and farmer participation in farmers' group has a significant influence on the farmer's decision to use organic fertilizers. While the number of family members, the experience, and the status of land ownership does not significantly influence the farmer's decision to use organic fertilizers.

Table 1 - Descriptive Statistics

\begin{tabular}{llll}
\hline Variable & Operational definition & Mean & Std. Dev \\
\hline Field school & 1 if the farmers join the field schools & 1.045 & 0.856 \\
& O if others & 3.341 & 1.221 \\
Hhsize & Number of family members (individual) & 51.818 & 9.842 \\
Age & Age of household head (years) & 7.500 & 4.339 \\
Educ. & level of education of household head (years) & 24.193 & 12.733 \\
Exp & experience of the head of the household to be farmers (Years) & 0.647 & 0.480 \\
Farm group & 1 if it participates in the farmer groups; 0 on the other & 0.909 & 0.289 \\
Yield status & 1 if they own; 0 if other & 7071.679 & 1062.264 \\
Production & kilograms per-season production & &
\end{tabular}

The next visits of the correlation between the independent variables with the farmer's decision to adopt organic farming unknown field school, farmers age, level of education, participation in farmers' group were positively related to the farmer's decision to use organic fertilizers organic.

\section{a. Field school:}

Field schools have a significant and positive effect on the chances of farmers to use organic fertilizers. This means that the field school can increase the farmer's decision to use organic fertilizers. Provision of training materials in agriculture will certainly build farmers' perceptions about the sustainability of agriculture. awareness of farmers will grow to step away from the use of chemicals when they are aware of the negative impact of the use of chemicals in agriculture. (Läpple, 2010) said information about the risks of the use of agricultural chemicals will raise the awareness of farmers to minimize the use of chemicals.

b. Age of Farmers:

Age has a positive and significant effect on the chances of farmers to adopt organic farming. it implies the higher the chances of farmers aged farmers to adopt organic farming will increase (Läpple \& Van Rensburg, 2011) argue, increasing age of farmers' dining opportunities to adopt new technology will increase, but at some point, as it ages farmer, their productivity will decrease, neither the chances of farmers to adopt organic farming.

\section{c. Education:}

The education level of the farmers has a positive and significant impact on the decision to adopt agricultural-organic farmers. This means that the higher the level of education that is taken by the farmer, their chances to adopt organic farming has increased as well. This finding is not surprising, with increasing education course taken by the farmer insight and knowledge they will be higher as well. About organic farming, farmers with higher education have a high awareness of the importance of organic farming in agricultural sustainability. In line with the results of the research (Kallas, et al, 2010; Mzoughi, 2011) also found similar results.

d. Farmer groups:

Participation in farmer groups has positive and significant impact on the chances of farmers to adopt organic farming. This finding suggests that farmers participating in farmer groups have a higher chance for the adoption of organic farming. This finding is in line with (Kallas et al., 2010). He said that social capital is one farmers' group is highly influential resources in farming activities. Most of the farmers' group has a goal-oriented in the long term, so it was no surprise when the farmers participating in farmer groups they tend weeks to the adoption of organic farming with the aim of sustaining their farming activities in the long term. 
Table 2 - Logit Regression Analysis

\begin{tabular}{lllll}
\hline Organic farming & Coef. & Std. Err & Z & Sig. \\
\hline Field school & 2.352806 & 0.656751 & 3.58 & $0.000^{* * *}$ \\
Hhsize & -0.41094 & 0.258506 & -1.59 & 0.112 \\
Age & 0.091136 & 0.046179 & 1.97 & $0.048^{* \star}$ \\
Educ & 0.322425 & 0.114304 & 2.82 & $0.005^{* * \star}$ \\
Exp & -0.01626 & 0.030752 & -0.53 & 0.597 \\
Farm group & 1.536635 & 0.657954 & 2.34 & $0.020^{* *}$ \\
Yieldstatus & 1.812033 & 1.545396 & 1.17 & 0.241 \\
Producton & -9.43864 & 3.238686 & -2.91 & 0.004 \\
\hline
\end{tabular}

Log likelihood $=-12.855488$

LR $\operatorname{chi} 2(7)=92.57$

Prob $>$ chi2 $=0.0000$

Pseudo R2 $=0.7826$

Source: ${ }^{* * *}=\operatorname{sig} 1 \% ;{ }^{* *}=\operatorname{sig} 5 \% ;{ }^{*}=\operatorname{sig} 10 \%$.

The results of the analysis of propensity score matching (PSM) is shown in Table 2. Prior to matching the estimation results obtained difference farmers using organic fertilizers and use of 401.22. Furthermore, after matching with the Propensity Score obtained a difference of 1659.68. This shows that farmers who use organic fertilizer have higher production than farmers who do not use organic fertilizer by $1659.68 \mathrm{~kg}$. From these results we can know that the use of organic fertilizer had a positive impact on agricultural production. These findings prove that the use of excessive chemicals would disrupt agricultural productivity in the long term. The use of chemical fertilizers in the District Ngawi been done long ago and indeed affects the sustainability of agriculture in the present and future (Kuntyastuti, et al., 2011; Suprapto, Ardhi, \& Apriandi). Awareness of farmers in minimizing the use of organic fertilizer capable of providing higher productivity and more sustainable.

Table 2 - Propensity Score Matching

\begin{tabular}{|c|c|c|c|c|c|c|}
\hline Variable & Sample & Treated & Controls & Difference & S.E. & T-stat \\
\hline Production & $\begin{array}{l}\text { Unmatched } \\
\text { ATT }\end{array}$ & $\begin{array}{l}7231.25 \\
7231.25\end{array}$ & $\begin{array}{l}6830.03 \\
5571.56\end{array}$ & $\begin{array}{l}401.22 \\
1659.68\end{array}$ & $\begin{array}{l}228.65 \\
1179.75\end{array}$ & $\begin{array}{l}1.75 \\
1.41\end{array}$ \\
\hline
\end{tabular}

\section{CONCLUSION}

Based on the discussion of the results it can be concluded that the field school, farmers age, educational level of farmers and farmers' participation in the group has a positive and significant impact on farmer's decision to use organic fertilizers. Furthermore, PSM analysis results showed that farmers use organic fertilizers have a higher production than the farmer who does not use organic fertilizers and means the use of organic fertilizers positive effect on agricultural productivity.

\section{REFERENCES}

1. Carvalho, F. P. (2006). Agriculture, pesticides, food security and food safety. Environmental science \& policy, 9(7-8), 685-692.

2. Deknock, A., De Troyer, N., Houbraken, M., Dominguez-Granda, L., Nolivos, I., Van Echelpoel, W., Goethals, P. (2019). Distribution of agricultural pesticides in the freshwater environment of the Guayas river basin (Ecuador). Science of the Total Environment, 646, 996-1008.

3. Alavanja, M. C. (2009). Introduction: Pesticides use and exposure, extensive worldwide. Reviews on environmental health, 24(4), 303-310.

4. Boone, L., Roldán-Ruiz, I., Muylle, H., \& Dewulf, J. (2019). Environmental sustainability of conventional and organic farming: Accounting for ecosystem services in life cycle assessment. Science of the Total Environment, 695, 133841. 
5. Jayakumar, S., Muralidharan, S., \& Dhananjayan, V. (2020). Organochlorine Pesticide Residues Among Colonial Nesting Birds in Tamil Nadu, India: A Maiden Assessment from Their Breeding Grounds. Archives of Environmental Contamination and Toxicology, 1-13.

6. Miller, D., \& Meek, F. (2004). Cost and efficacy comparison of integrated pest management strategies with monthly spray insecticide applications for German cockroach (Dictyoptera: Blattellidae) control in public housing. Journal of economic entomology, 97(2), 559-569.

7. Mfarrej, M. F. B., \& Rara, F. M. (2019). Competitive, sustainable natural pesticides. Acta Ecologica Sinica, 39(2), 145-151.

8. Jenni, A., Suhartono, S., \& Nurjazuli, N. (2014). Hubungan Riwayat Paparan Pestisida dengan Kejadian Gangguan Fungsi Hati (Studi Pada Wanita Usia Subur di Daerah Pertanian Kota Batu). Jurnal Kesehatan Lingkungan Indonesia, 13(2), 62-65.

9. Cacek, T., \& Langner, L. L. (1986). The economic implications of organic farming. American Journal of Alternative Agriculture, 1(1), 25-29.

10. Eyhorn, F., Muller, A., Reganold, J. P., Frison, E., Herren, H. R., Luttikholt, L., Seufert, V. (2019). Sustainability in global agriculture driven by organic farming. Nature Sustainability, 2(4), 253-255.

11. Shahrajabian, M. H., Sun, W., \& Cheng, Q. (2019). Traditional Chinese medicine and agriculture; organic life and sustainability for future. GSC Biological and Pharmaceutical Sciences, 7(1), 091-095.

12. Rosenbaum, P. R., \& Rubin, D. B. (1985). Constructing a control group using multivariate matched sampling methods that incorporate the propensity score. The American Statistician, 39(1), 33-38.

13. Läpple, D. (2010). Adoption and abandonment of organic farming: an empirical investigation of the Irish drystock sector. Journal of Agricultural Economics, 61(3), 697714.

14. Läpple, D., \& Van Rensburg, T. (2011). Adoption of organic farming: Are there differences between early and late adoption? Ecological Economics, 70(7), 1406-1414.

15. Kallas, Z., Serra, T., \& Gil, J. M. (2010). Farmers' objectives as determinants of organic farming adoption: The case of Catalonian vineyard production. Agricultural Economics, 41(5), 409-423.

16. Mzoughi, N. (2011). Farmers adoption of integrated crop protection and organic farming: Do moral and social concerns matter? Ecological Economics, 70(8), 1536-1545.

17. Kuntyastuti, H., Wijanarko, A., Purwaningrahayu, R., \& Taufiq, A. (2011). Pengaruh Residu Pupuk Organik dan NPK Terhadap Perubahan dan Kondisi Tanah Vertisol Ngawi pada Tanaman Kedelai. Paper presented at the Prosiding Seminar Hasil Penelitian Tanaman Aneka Kacang dan Umbi.

18. Suprapto, E., Ardhi, M. W., \& Apriandi, D (2018). Upaya Mewujudkan Sustainable Development Goals (Sdgs) Melalui Sistem Padi Organik Di Desa Pojok Kwadungan Ngawi. Prosiding Seminar Nasional Hasil Pengabdian Kepada Masyarakat Hilirisasi Hasil Penelitian Melalui Program Pengabdian Berkelanjutan Yogyakarta, 27 Oktober 2018 86p. 